\title{
Exploring the Literary Representation of Trauma in Contemporary Iraqi Fiction from Socio-historical Perspective
}

\author{
Sayed M. Ismail Mousa ${ }^{1} \&$ Dr. Ghassan Nawaf Jaber Alhomoud ${ }^{1}$ \\ ${ }^{1}$ Prince Sattam Bin Abdulaziz University, Kingdom of Saudi Arabia \\ Correspondence: Dr. Sayed M. Ismail Mousa, Prince Sattam Bin Abdulaziz University, Kingdom of Saudi Arabia.
}

Received: December 20, 2021

Accepted: January 20, $2022 \quad$ Online Published: January 28, 2022

doi:10.5430/wjel.v12n1p162

URL: https://doi.org/10.5430/wjel.v12n1p162

\begin{abstract}
The present study aims to critically review the aspects of war in selected Iraqi war novels - Sinan Antoon, The Baghdad Eucharist (2017), Corpse Washer (2013) Zauhair Jabouri, The Corpse Hunter (2014) - that focus on depicting vividly the traumatic experiences of Iraqi, particularly after the US-led invasion of Iraq 2003 and how these novels could recur constantly to humanist themes and traumatized figures, the psychological suffering of minorities and the oppressed. In other words, it aims to make visible specific historical instances of trauma in Iraqi war fiction. The present study undertakes an in-depth investigation of the socio-political and historical dimensions of Cathy Caruth's literary trauma simply because trauma experiences in Iraq were emanated from several causes such as social injustice, the oppression of minorities, political despotism, and the persecution of religious minorities, the displacement of Iraqis from the homeland, and the genocidal policies of jihadist. The study has found that Iraqi war fiction depends on the stylistic technique of repeating certain expressions, phrases, and lexical items to intensify the extraordinary events. It is a narrative of traumatic haunting known for its non-linear and circular style that often leads to ambiguity where readers are often unable to decode the authorial intentions, deriving its ambiguity from the traits of dreams and nightmares, the interpretations of which are continually and unredeemably haunted by the memory of loss.
\end{abstract}

Keywords: circular narrative, Iraqi War Fiction, literary trauma, nightmares

\section{Introduction}

The historical situations in which the selected war fiction novels are written were complex, to say the least, and without any exposition on this, it is difficult to understand the significance of the novels in terms of how they represent war and history and how they represent the traumatic experience in Iraq. It is important therefore to start with exposing the historical context in which Iraqi war fiction was written and how such a historical context, which was replete with wars, explosions, genocide, was portrayed in war fiction and how it could contribute to representing the collective traumatic conditions of Iraqi people. Since Saddam Hussein's ascent to power, becoming the president of Iraq in 1979, Iraq has been subjected to violent conflicts and wars both domestically and regionally, which included the Iraq-Iran war, the Iraqi-Kurdish conflict, Gulf War, the 2003 invasion of Iraq, and the emergence of ISIS. This series of consecutive wars has made millions of Iraqi victims of atrocities, torture, and traumatic experiences. This current study aims to investigate the representation of trauma in Iraqi war literature by highlighting how Iraqi literature has been strongly influenced by the complex psychological, social, and historical factors that influence authors and their works. Thus, the current study examines the Iraqi narratives that depict the psychological suffering, feeling of internal alienation, loss of identity, estrangement, and the emergence of terrorist groups like ISIS, the repercussions of which were not limited to the survivors of the traumatic experiences but were transferred to the next generation born after the end of the Iraq war.

Many Iraqi writers have found that writing is an effective means by which they can give voice to their wounds and depict their traumatic experiences. The Iraqi war narrative has come to be a representation of the mental and psychological effects of the war. Iraqi war novels serve as a testimony to the trauma of the whole country, examining how war narratives use the devastating emotional impact of wars and conflicts in Iraq to reflect on the period beginning with the first Gulf war until the American occupation of Iraq in 2003, coupled with the emergence of ISIS in Iraqi history, exploring ways of representing the Iraqi traumatic experience (e.g. surrealistic elements, nonlinearity, fragmentation, nonlinearity, and the use of nightmares), and examining the representation of the interrelated themes of trauma, identity, history, and memory manifested through traumatic symptoms, such as flashbacks and nightmares, 
helplessness and surrender, inner deadness, distorted views of the present and the future, alienation, disorientation, and a strong diasporic urge.

Although I conceded that traumatic experiences are analyzed in terms of psychoanalysis criticism, I still maintain that Iraqi traumatic experiences have to be examined in light of Iraqi's cultural, social, and historical context. Therefore, Iraqi traumatic experiences should be dealt differently from Western traumatic experiences, as each traumatic experience has its special conditions which make it unique and distinctive in itself. Caruth (1995) claims traumatic experience should reclaim its past, and I have a mixed feeling about it. On the on hand, I agree that the idea of reclaiming the past of traumatic experience requires us to focus on the discrepant historical experience shared by the traumatized person and his/her oppressor, which requires a contrapuntal reading represented by Said's Culture and Imperialism (1993), where the two histories of the oppressor and oppressed should be read side by side. On the other hand, I still insist that the idea of reclaiming the historical experience is paradoxical and unachievable in the sense that traumatized person forgets all about his traumatic experience. Therefore, examining the traumatic experience from a historical perspective is a highly controversial issue. In an attempt to resolve such a controversy, the current study is mainly interested in critically reviewing the aspects of war in selected Iraqi war novels - Sinan Antoon, The Baghdad Eucharist (2017), Corpse Washer(2013) Zauhair Jabouri, The Corpse Hunter (2014 ) - that focus on depicting vividly the traumatic experiences of Iraqi, particularly after the US-led invasion of Iraq 2003 and how these novels could narrate the experiences and the stories of traumatized persons, the psychological suffering of minorities and the oppressed. Indeed, there are definite criteria for selecting specific novels: 1) these novels were written after the US-led invasion of Iraq. 2) These novels explore the repercussions of the American invasion of the Iraqi people. 3) They focused on revealing the psychological repercussions of war on minorities and marginalized like Christians, Yazidis, Shia, and so on.

In the face of the overwhelming war traumas of the twentieth and first twentieth centuries, a controversial issue has been whether the literary representation of the Iraqi traumatic experiences in Iraqi war fiction were confined only to the victims of war and causalities, who were exposed to extremely violent events, or to those people who suffered from prolonged periods of social repression, religious persecution, and the abolishment of the original identity that leaks into the future.. On the one hand, several critics (Bilal, 2018; Blasim, 2014; Hadla, 2020; Lewandowsky et al., 2005; Moosavi, 2015) claimed that traumatized cases in Iraqi fiction belong to the war trauma category in which people were exposed to body extermination and multination, on the other hand, others (Evans, 2003; Farid, 2015; Ghazoul;2015; Hanoosh, 2013; Milich, et al, 2012) argued that the traumatic experience of Iraqi people resulted from prolonged socioeconomic crises and social injustice, religious bullying and intimidation, all of which are produced by wars. That is to say, war is not the main reason behind the traumatic experiences of the Iraqi people. Rather, its repercussions and negative effects contributed to creating fertile soil for the rapid growth of traumatic experiences not only across Iraq but also across other neighboring Arab countries. Therefore, the present study adopts a broader concept of trauma, the social trauma that corresponds to the drastic and brutal realities of the Arab citizens and their diminishing hopes for a better life. Even more explicitly, the present study aims to undertake an in-depth investigation of the socio-political dimension of trauma simply because trauma experiences in Iraq were driven by several causes such as social injustice, the oppression of minorities, political despotism, and the persecution of religious minorities, the displacement of Iraqis from the homeland, and the genocidal policies of jihadist. These negative consequences resulted from several wars that occurred in Iraq and results in chronic and severe conditions of life. These chronic life conditions have continued to exercise their impact on Iraqi for more than three decades targeting the groups of disenfranchised and disempowered people.

\section{Literature Review}

Although Iraqi war narratives exhibit several characteristic features such as the repetitive compulsive nature of trauma experienced, the dissociation of the psyche, the repressed memory, the unspeakable nature of the traumatized experience, the loss of identity, the distortion of the present, and the escape from the past, the analysis of Iraqi literature from the perspective of social trauma perspective has not been given due attention. Studies related to the effect of social trauma presented in the Iraqi narrative are still very few. These studies include Writing Trauma in Iraq: Literary Representations of War and Oppression in the Fiction of Sinan Antoon (2015) by Habeeb. Habeeb (2015) remarks that the literary representation of traumatic experiences in Iraqi fiction is fairly limited compared to its counterpart in Western literature. She traces the traumatic experiences described in Sinan Antoon's two novels I'jaam: An Iraqi Rhapsody and The Corpse Washer which address the physical and psychological trauma of wars and prolonged years of oppression in Iraq. Other studies addressed the traumatic experiences of Iraqi women. Al-taleb (1983) wrote one of the earliest studies addressing the literature of war in Iraqi fiction, tracing the history of Iraqi war fiction from the Second World War until the Iraqi Iran war and exposing the repercussions of the Iraq-Iran war on Iraqi people. Published by Sciedu Press 
Masmoudi(2010) examines the depiction of Iraqi women in Iraqi war fiction. Masmoudi writes, "as women lose their fathers and husbands to violence, they find themselves taking part in conflicts, participating in strategies of survival, and sometimes assuming prominent positions in their families and societies"(p.1). Women's suffering and oppression were described in Iraqi narratives particularly after 2003 when Saddam Hussein's presidency ended. The women writers use fiction to record and historicize the suffering, oppression and dispossession of Iraqi women. Hamedawi (2017) addresses the oppression and traumatic experiences encountered by women in Arab culture using very classical expressions, like, al-maw 'udah (the buried infant girl) and Shahrazad (a fictional traditional woman who symbolizes the oppressive conditions of women) to demonstrate the extent to which extent Arab women are intimated, oppressed, and marginalized.

Little has been done to address the gap between postcolonial criticism and literary trauma. Hamedawi (2017) addresses the impact of the American occupation of Iraq in 2003, coupled with the emergence of ISIS, on the Iraqi war fiction. The American occupation of Iraq and the emergence of ISIS were sources of inspiration for Iraqi novelists, as the postcolonial themes like the relationship between the colonized and colonizer, and the oppressed and oppressor had begun to be dominant themes in Iraqi war novels. Hamedawi argues that the Iraqi postcolonial novel has emerged as unique in its style, which ranges from realistic vision, imaginative world, and speculative nature to mythical realm. In addition, it varies from rough objectivity to subjective sympathy (p.2). The Iraqi postcolonial novels were preoccupied with violence, corruption, death, and traumatic experiences. However, the concept of trauma was not adequately addressed in the same manner as it is dealt with in Western novels depicting the First and the Second World Wars and the Vietnam War. In addition, the studies focused on the postcolonial themes were portrayed in the novels without considering the possibility of studying Iraqi traumatic experiences in the light of postcolonial criticism. That is to say, the idea of bridging the gap between traumatic experience representation in narrative and postcolonial criticism represents a shred of crystal-clear evidence to the oppressive and gloomy atmosphere befalling Iraqis, which is characterized by alienation, weakness, stagnation, and resignation.

The previous studies have not directly focused on the consequences of traumatic experience in the Iraqi postcolonial novel, as their attention was on the causes of traumatic experience instead of on the trauma itself and its repercussions. To illustrate, Saadaw (2014), mimics the Western Frankenstein novel but gives it a different treatment, as the Western Frankenstein was a direct result of the negative exploitation of the development of science in Europe. The Iraqi Frankenstein is Hadi, a junk dealer, who collects the body parts of people who have been the victims of suicide bombs and sews them together so that the complete corpse can be buried properly and found peace in the hereafter. It is clear that the causes of traumatic experiences have been vividly described, but the trauma itself and its consequences have been neglected. Kachach (2008) tackles the repercussions of the American occupation of Iraqi from a different perspective, dwelling on the tragic effects of cultural hybridization with the central theme of conflicting identities and loyalties. Firmani (2018) argued that Iraqi war fiction is always notorious for its dark cast and its description of death which can be easily traced in the narrative fiction of Hassan Blasim's 2014, Sinan Antoon's novels, and so on. The Iraqi war fiction has been characterized by its description of death. In describing death, Iraqi fiction embraced gothic, surrealist, and absurdist elements. Masmoudi (2015) examined the accounts of the Iraqi war after the overthrow of Saddam Hussein's regime and the occupation of Iraq by American forces. Masmoudi argues that the literary representation of Iraqi wars is dominated by the terror of tyranny and the brutalities of war and occupation. She has reviewed numerous novels and relies heavily on works written by men who, for the most part, live abroad, positing that "the Iraqi novel has become a representation of the manifestation of sovereign power, examining how the individual Iraqi has coped with and withstood the subjugation of life to the power of death and killing"(p.20). Masmoudi remarked that Iraqi fiction has focused attention on the representation of death experiences of ordinary Iraqi people who were involved in war conditions, arguing that such types of characters are "united by the fact that they all are doomed to a living death in a context of the lawlessness of war and the state of emergency and exception that it creates"(p.25). This state of lawlessness and random death has been figured out as a bystander to the overwhelming chaotic atmosphere of death and killing portraying the surliest, absurdist, circular, and fuzzy narrative line that distinguished the Iraqi war fiction. Firmani (2018) argued that such an ambiguous and confusing context has to be coupled with broken and fragmented narratives which never flow from a steady stream of consciousness; this narrative type, however, is notorious for its disruption, intermittence, lack of coherence, and its limitless interpretations.

O'Gorman (2015) states that Iraqi war fiction draws heavily on fragmented textuality, the context of which is based on disrupted reality, collapsed setting, and multidirectional memory that leaves open space for contradictory readings and multiple interpretations. O'Gorman discussed three fictional texts engaged with the recent Iraq war. These novels are Point Omega by Don DeLillo (2010), Gods Without Men by Hari Kunzru (2011), and The Yellow Birds by Kevin Powers (2012). These novels are meant to highlight the ties and nexus between American foreign policy after $9 / 11$ and 
the eruption of wars and violence in the Middle East (76). That is to say, these novels have focused on the consequences of the American War on Iraqi people as they redressed what is described as dehumanizing and indifferent to people's psychological and physical suffering. In this way, these novels bridged the gap between postcolonial literature and literary trauma. Mousa (2018) argued that war is not a mere story in the life of Iraqis. Rather, war is an everlasting and permanent condition that inflicts its harm on every Iraqi family, beginning in 1980 and lasting to the present day. Most Iraqi writers not only witnessed these wars but were affected by their devastating effects and brutalities. As such, war has had a significant influence on Iraqi fiction. Mousa addressed the negative psychological effects of war on the Iraqis, as she remarks that war cannot be confined only to military fighting and war tunnels but also has psychological and ethical destruction upon civilians. War results in an orphanage, familial miseries, the death of beloved ones and sons. The Iraqi war fiction not only documents such miserable and devastating conditions of Iraqis and the calamities and catastrophes inflicted on them but also exposes the humanistic and psychological suffering of war victims.

\section{Theoretical Framework}

Traumatic experiences in Iraqi war fiction should be examined in relation to both psychoanalysis theory and history. To achieve its end, the current study dwells upon the trauma literary theories of Caruth (1995) that draws on Freudian theories of trauma in the sense that trauma is "not locatable in the simple violent or original event in the individual's past" but is identified only in "the way it is precisely not known in the first instance - returns to haunt the survivor later on" (Caruth, 1995, p.174). Furthermore, Caruth examined the traumatic experience within the confines of the parallel historical experience and socio-economic realities, holding a belief that traumatic narrative should be studied concerning its historical experience. "The historical power of the trauma is not just that the experience is repeated after its forgetting, but that it is only in and through its inherent forgetting that it is first experienced at all" (Caruth, 1995, p.8). Traumatic experience historically develops in the sense that it continues to progress alongside historical events, making it seem as if it is history that traumatizes. In this way, trauma experience is a renewed and transformative historical experience and it is also transgenerational. Whitehead (2004) remarked that "trauma is not a symptom of the unconscious but of history. The event is not experienced as it occurs but is fully evident in connection with another place and in other time"(p.12). kolk et al. (1999) connect history to trauma: a remark that traumatic experience is a historical experience par excellence since it is experienced by a man who is the maker and writer of history. As Erikson (1991) explains that trauma is often accompanied by a prolonged exposure to terrors and violence and threats that make the members of a community share in common a similar ordeal and suffer from psychic erosion (p.460). Since Iraq has undergone a lengthy period of war, poverty, lack of social injustice, and social equity, which has started since the eighties of the last century and has not been ended yet, the present study relies on Caruth's theory of trauma in the light what Judith Herman (2015) calls "prolonged trauma" or a trauma repeated for an extended period. The prolonged trauma refers to long-standing situations of human suffering due to captivity, imprisonment, concentration camps, solitary confinements, and so on the servitude of laborers, religious cults, brothels, sexual abuse, and even oppressive family relationships (Herman, p.74). Despite what is described by Herman represents the Holocaust and the extended suffering of Jews at the hands of the Nazis, it is corresponding to the suffering of Iraqis due to the lengthy Iraqi war accompanied with a prolonged trauma. To further tighten its methods, the present study also adopts the concept of insidious trauma. Root (1996) explains that insidious trauma is "usually associated with the social status of an individual being devalued because a characteristic intrinsic to their identity is different from what is valued by those in power" and illustrates how this kind of experience indirectly but insidiously becomes a "distinct threat to psychological safety, security, or survival" (p.366).

\section{Discussion and Analysis}

The present study has focused on critically reviewing the traumatic experiences in the Iraqi war fiction written in the period after the US-led invasion of Iraq and reviews critically some novels by Antoon, The Baghdad Eucharist,(2017) Corpse Washer (2013), and by Jabouri, the Corpse Hunter (2014) by examining a set of literary techniques like flashbacks and nightmares, weakness and withdrawal, submission and fear, inner-self vacuum, pessimistic vision of the present and the future, alienation, and, insidious trauma. Therefore, the scope of investigation of traumatized cases in the Iraqi narrative under the current study will not only focus on the representation of psychologically traumatized people but also on the marginalized and socially disempowered people. The first war fiction novel to be examined is The Baghdad Eucharist written by Antoon. Antoon is a poet, novelist, translator, and scholar. He was born and raised in Baghdad to a Christian family where Christians represent a minority in Iraq who were exposed to religious persecution and torture and displacement at the hands of terrorist groups. He completed his B. A in English at Baghdad University in 1990. He left for the United States after the 1991 Gulf war. He pursued his education at Georgetown and Harvard. He obtained his Ph.D. in Arabic literature from Harvard in 2006. He wrote several war novels that vividly Published by Sciedu Press 
describe the suffering of Iraqi people resulting from wars and social injustice and bad conditions of minorities. His works are colored by a pessimistic vision toward the future of Iraq, where his memories of oppression, injustice, and the smell of death have dominated his several novels.

The Baghdad Eucharist describes the serious repercussions of war on the Christian minority in Iraq and the religious persecution to which they were exposed at the hands of terrorist movements as well as their displacement from their historical homeland. Antoon ventilates the pathetic stories of marginalization, oppression, and annihilation befalling the Christians of Iraq who were bitterly divided between the tortures of fleeing from their homeland and the pains of remaining unprotected and deprived of their personal and religious freedom. This prolonged feeling of insecurity, disempowerment, and marginalization instilled a feeling of contaminated identity into their minds, which is a syndrome of trauma. Their traumatic wounds do not heal over time and are not susceptible to recovery. The novel traces the experiences of dislocation and estrangement faced by Maha, the heroine of the novel, who underwent an intensely traumatic experience and a permanent feeling of depression due to her loss of pregnancy and the destruction of her home in a terrorist suicide attack targeting an area inhabited by the Christians of Iraq. Maha seems to have been doomed to an endless and interminable repetition of such painful memories. The intermittent eruption of these painful memories turns her life into dreadful. The traumatic experience has been clearly shown in the resonance of her voice while she was always saying in an Iraqi accent, maku aml, which means, "there is no hope." She therefore forcefully rejects the prospect of eternal rest. After the terrorists exploded her house including the houses of many neighboring Christians, she has become unsheltered and a refugee in her homeland. The feeling of estrangement and loss in his homeland deepens the trauma experience for the Christians of Iraq and made her unable to face the more disturbing aspects of reality, as she was deranged. Maha was obliged to seek refuge in the house of one of her relatives, named Youssef, a Christian old man who underwent numerous calamities and catastrophes but still adheres to his vanished hope of staying in Iraq, refusing to leave his homeland.

Collapsing the borders between fact and fiction in an unprecedented manner, Antoon relies on dialecticism in fictionalizing the trauma by offering two antagonistic visions. The first vision is adopted by the old man, Youssef who keeps dreaming of the possibility of co-existence in Iraq and was against the division of human reality. He refused to surrender to reductionist and essentialist ideas that fragment human reality into conflicting fragments; Muslims versus Christians; Sunni versus Shia; black versus white and so on. His vision seems to reflect a kind of reconciliation with his surrounding reality. However, on a deeper level, it reveals an indiscernible or imperceptible intense to the untrained eye, an inner struggle inside the heart and the mind of Youssef, a kind of latent trauma that he tries to suppress by adopting optimistic and conciliatory vision and mingling fact with fantasy. The second vision is that one adopted by Maha, which both is pessimistic and realistic. The trauma of Maha is expressly articulated in her belief that this place is no longer valid to be her motherland where she leads her life as a refugee and unsheltered, trying to find escape outside Iraq. Although she survived unscathed all of the dangers threatening her, the loss of her pregnancy symbolizes the end of her hopes to remain living in Iraq and the impossibility of sowing seeds of life upon such a waste and infertile land. Antoon employs symbolism through surrealistic images and motifs in fictionalizing the traumatic experience of Maha. She suffers from such traumatic disorders, which resulted from a contaminated identity, social disempowerment and lack of insecurity, and marginalization. It seems that Maha suffers from "insidious trauma," which results from "long-term effects of oppression the psychological impact of which can be perceived in terms "insidious trauma." The novel was ended by the explosion of Salvation Church by the terrorists where Youssef was among the casualties, triumphing for pessimism over-optimism, and trauma over peace and tranquility.

The Baghdad Eucharist is a loud cry of oppression to heal the deadly wounds of the Christian worshippers who were slaughtered at the hands of ISIS members at the Church of the Savoir in Iraq. The condition of permanent loss of hope is the severest type of traumatic experience. This cry of pain to Mary is allusive in the sense that it reminds us of the passions of Christ, the savior on the day of the crucifixion where he saved humanity by his blood. This cry to Mary is predominantly read as a historical testimony unspeakable by the traumatized Iraqi people who have lost salvation in the world and instead have sought it in heaven. The Baghdad Eucharist reincarnates the displacement of Iraqi Christians and their extinction from their historic homeland, which has started at an accelerated pace since the US-led invasion. On the superficial level, the story seems to follow an explicit chronological line which makes it easy to determine the specific dates of the story. Although it is easy to determine the beginning of the story, its end seems to be open and difficult to determine. The incidents of the story occur in one day. Despite the idea that the narrator changes from chapter to chapter, the plot is cohesive and coherent. A traumatic experience can be easily shown in the triumph of pessimistic vision over the optimistic where the hopes of Youssef, the hero of the novel for a better future for the minorities in Iraq and the possibility of co-existence have been shattered when he was killed in a suicide attack targeting the worshipers in the Church. Antoon was keen enough to represent the violent, sad, and brutal endings of his 
characters whose memories were substituted with the assiduous collection of remains, testimonies, images, and an endlessly proliferating construction of belated memories.

Youssef's destiny is not different, at any rate, from that of Jawad, the protagonist of the Corpse Washer (2013), which is also written by Antoon and translated by the same author. The Corpse Washer is highly connotative in the sense that it connotes death, pessimism, sadness, catastrophes, and calamities which are closely related to death and traumatic experiences. It also portrays a gloomy and dark scene replete with causalities and deaths that requires a corpse washer to wash the dead bodies before sending them to their final destination. The Corpse Washer is narrated by Jawad where Antoon uses the first person narrative technique. Jawad came from a Shi' ite family located in Baghdad. Jawad's father is a corpse washer by inheritance, as he inherited this job from his father who trained him on how to wash the dead people before their burial. His father and his brother were killed in the Iraqi devastating wars that forced him to take his father's job as a corpse washer. The story is considered to be a striking example of a traumatic experience, as it is started with a nightmare narrated by Jawad where he found himself obliged to wash the corpse of his girlfriend. Before he started washing the corpse of her beloved, he was slaughtered by terrorists and witnessed his head rolling on the ground. He says: "I feel a sharp pain, then the cold blade of the knife penetrating my neck. Hot blood spills over my chest and back. My head falls to the ground and rolls like a ball on the sand...I see my body to the left of the bench, kneeling in a puddle of blood"( Antoon, 2013,p. 2).

This novel is replete with terrifying nightmares, which display the images of death and have a dominant presence in the narrative of the novel, and the protagonist seems unable to escape its shadow. These nightmares are always a montage of forgotten or suppressed traumatic experiences, recomposed by the protagonist. The narrative draws heavily on intermittent and fragmented nightmares that take on death scenes representing dissociated memories. These dispersed memories cannot be transformed into personal fiction but continue to grow as annoying perceptions, terrible visions, horrible nightmares that lead to anxiety and devastating reactions. Drawing together the separate lines of these intermittent nightmares, one can conclude that their histories are inextricably intertwined and overlapped through a series of identical events and submerged images. These identical events and submerged images have taken different forms like flashbacks or repeated horrible scenes, standing for some of the key literary devices representing trauma. The narrative style in the novel draws heavily on the stylistic repetition where certain phrases are used with different senses and always connote different concepts reinforcing the circularity of the narrative and its fragmentation. The non-linear style of narrative often leads to ambiguity because it conceals the authorial intentions, which are identical with the traits of dreams and nightmares. The stylistic devices employed in the novel pour themselves into the gaps between fragments, like so much mortar.

From the Corpse Washer to the Corpse Hunter"(2014), an untranslated novel written by Zuhair Al-jaboury, the smell of death has not left us and the lexical item "corpse" has its resonance everywhere. It seems that the term corpse has been recurrently used in Iraqi war fiction to signify trauma. Al-jaboury's vision flows from the same spring from which the thoughts and ideas of Antoon have flowed. Al-jaboury agrees with Antoon's pessimistic vision about the dark future of Iraq where he stated that traumatic experience is also epitomized in the loss of hope of returning to the homeland. The novel narrates the story of the protagonist named Ghaib, non-present. The choice of the lexical item "Ghaib" is symbolic that elicits the eagerness of the reader to explore the stories of an Iraqi migrant who decided to return to his home after spending 15 years abroad. Whilst his family members were waiting for his arrival at the airport, the terrorists kidnapped him, his brother, and his nephew. The kidnap of Ghaib has a traumatic effect on the whole members of his family and bears witness to those who were lost. Haj Mohammed, the father of Ghaib, was in a devastating condition and started a painful journey pursuing the corpses of his two sons. Haj Mohammed was accustomed to the smell of death and lost his desire to live, and became under the overwhelming impact of trauma. His mother turned into a sad and powerless woman who no longer endured the pains of life, as she immersed herself too deeply in the past/ She also suffered from the traumatic experience. Amal, the daughter of Ghaib, whose father left her when she was at the age of 2 years, kept dreaming of her father's return to her homeland. However, her dream was vanished and went with the winds due to his kidnapping. Amal is also a symbolic name that refers to hope and dream of achieving a good future for Iraq; however, such hope is Ghaib, absent. What is strikingly noticed is that what I call "Negative Dialecticism" between pessimism and optimism has become a dominating stylistic device coloring the Iraqi war fiction, in which triumph always goes hand in hand with the pessimistic vision.

Iraqi war fiction depends on the stylistic technique of repeating certain expressions, phrases, and lexical items like mako $\mathrm{Aml}$, there is no hope, al-aml al-ghaib, the absence of hope to intensify the severe and devastating traumatic experiences which the collective consciousness of Iraqi underwent during the prolonged wartime. There was a diminishing hope that Ghaib, the absent father, would be present and come back. There was also a diminishing hope that peace, justice, and equality will start to rise again in Iraq. Here, the traumatic experience is mainly centered on the idea of the loss of hope. Published by Sciedu Press 
The concept of absence is very traumatic in itself. This novel reveals the miserable conditions of Iraqi where hundreds of people died every day and many people turned into criminals and killers after long years of oppression and repression. This division of human reality and identity, which is naturally undivided, and hence the importance of decoding the intermittent and disrupted memories and stories of traumatic experiences, are significant themes in the novel. The novel manifested the brutality of the killing, the mutilation of dead bodies, which results in a large number of traumatic experiences. Whitehead (2004) argued that trauma fiction draws heavily on the technique of repetition which can take different shapes and patterns ranging from linguistics, visual, to perceptual. Repetition can take its effect and force from imitating and repeating traces, events, and incidents accompanied to trauma. The traumatic effect is permanent but invisible which frequently haunts the traumatized person and this repetition can be best represented by disruption of narrative chronology or progression that defies linear time through interruptions and the interference of flashbacks. This novel narrated the traumatic history of the whole Iraqi people. Trauma experience was a collective and overwhelming experience that is shared by the politically oppressed, and the religiously intimated Iraqis.

\section{Conclusions}

The selected novels serve as a cultural repository of sorts for how these wars are remembered. Wars generate a wide range of consequences affecting political-economic structures; social institutions; everyday, intimate life. Trauma experienced in Iraq has been emanated from several causes such as social injustice, oppression of minorities, political despotism, and persecution of religious minorities, displacement of Iraqis from the homeland, and the genocidal policies of terrorists. The traumatic experiences depicted in these novels not only depend on the psychological effects stemming from the exposure to extremely violent events but they also draw heavily on the prolonged traumatic effect represented in extended periods of social repression, religious persecution, the abolishment of the original identity. The selected novels were dominated by the scene of death. This state of lawlessness and random death has been figured out as a bystander to the overwhelming chaotic atmosphere of death and killing portraying the surliest, absurdist, circular, and fuzzy narrative line that distinguished the Iraqi war fiction. This narrative type is notorious for its disruption, intermittence, lack of coherence, and its limitless interpretation. Flashbacks and nightmares, helplessness and surrender, inner deadness, distorted views of the present and the future, alienation, disorientation, insidious trauma were employed in Iraqi war fiction. The narrative draws heavily on intermittent and fragmented nightmares that take on death scenes, which represent dissociated memories. Drawing together the separate lines of these intermittent nightmares, one can undergo the ordeal and the unbearable psychological shock of the trauma experience. These nightmares have taken different forms like flashbacks or repeated horrible scenes, which represent some of the key literary devices representing trauma. The narrative style in the novel uses the device of stylistic repetition where certain phrases are used with different senses and always connote different concepts which reinforce the circularity of the narrative and its fragmentation. The non-linear style of the narrative often leads to ambiguity where readers are unable to understand exactly the authorial intentions, which are identical with the traits of dreams and nightmares, the interpretations of which are open and difficult to fix. What can be found out in such a novel is a literary testimony of the horror and terrors emanating from the war in Iraq where families of soldiers always used to receive the corpses of their sons. What is remarkably noticed in Iraqi war fiction Iraqi is its dependence on the stylistic technique of repeating certain expressions, phrases, and lexical items to intensify the extraordinary events which the collective consciousness of Iraqi comes across during the prolonged wartime. Repetition mimics the effects of trauma, for it suggests the insistent return of the event and the disruption of narrative chronology or progression.

\section{About Author}

Sayed Ismail is an Assistant Professor of Translation Studies and Comparative Literature at Prince Sattam Bin Abdulaziz University, Kingdom of Saudi Arabia. His research focus includes literary theory, translation theory, comparative literature, and philosophy.

\section{References}

Al-taleb, O. (1983). War in Iraqi Fiction. Publications of Ministry of Culture.

Antoon, S. (2013). The Corpse Washer. Trans. Sinan Antoon. Yale University Press.

Antoon, S. (2017). The Baghdad Eucharist. Trans. Maia Tabet. Hoopoe.

Blasim, H. (2014). The Corpse Exhibition and Other Stories of Iraq. Penguin Books.

Bilal, N. (2018). Contemporary Iraqi War Fiction: A Comparative Analysis of Selected Works by Sinan Antoon and Batool Khedairi. Unpublished M. A thesis, Beirut Arab University.

Caruth, C. (1995) Unclaimed Experience: Trauma, Narrative, and History. Johns Hopkins University Press. 
Erikson, K. (1991). Notes on Trauma and Community. American Imago, 48(4), 455-472. Retrived from http://www.jstor.org/stable/26303923

Evans, E. B. (2003). Iraq and the New American Colonialism. Moebius, 1(2), 47-50. Retrieved from http://digitalcommons.calpoly.edu/moebius/vol1/iss $2 / 10$

Farid, F. (2015). Sinan Antoon: an Iraqi novelist living in continuous mourning. The Guardian, Tue 3 Mar 2015, https://www.theguardian.com/books/2015/mar/03/sinan-antoon-iraq-ave-maria-

Firmani, M. (2018). At War with Monsters in Postwar Iraqi Literature. Los Angeles Review of Books. Retrieved from https://lareviewofbooks.org/article/at-war-with-monsters-in-postwar-iraqi-literature/2018

Ghazoul, F. J. (2014). Iraqi Short Fiction: The Unhomely at Home and Abroad. Journal of Arabic Literature, 35(1), 1-24. https://doi.org/10.1163/1570064041341888

Habeeb, Z. (2015). Writing Trauma in Iraq: Literary Representations of War and Oppression in the Fiction of Sinan Antoon. [ Unpublished Master's thesis].MSU Graduate.

Hanoosh, Y. (2013). Beyond the Trauma of War: Iraqi Literature Today. Words without Borders. 5. EBSCOhost.

Hadla, H. A. (2020). Endemic Trauma and the Cross-Cultural Gap: A study of Fiction about the 2003 American-Iraqi War. [Unpublished Doctoral Dissertation]. the University of Texas at Austin.

Herman, J. (2015). Trauma and Recovery: The Aftermath of Violence-From Domestic Abuse to Political Terror. Basic Books.

Hamedawi, S. (2017). The Postcolonial Iraqi Novel: Themes and Sources of Inspiration. Babel, 36(1), 211-228. https://doi.org/10.4000/babel.5043

Jabouri, Z. (2014). The Corpse Hunter. Athar Publication House.

Kachachi, I. (2008). The American Granddaughter. Trans. Nariman Youssif. Bloomsbury.

Kolk, V. Bessel, A., Farlane, M., Alexander, C., \& Weisaeth, L. (1996). The Effects of Overwhelming Experience on Mind, Body, and Society. Guilford Press.

Milich, S., Pannewick, F., \& Tramontini, L. (eds). (2012). Conflicting Narratives: War, Trauma, and Memory in Iraqi Culture. Reicher. https://doi.org/10.29091/9783752000993

Lewandowsky, S., Stritzke, W., Oberauer, K., \& Morales, M. (2005). Memory for fact, fiction, and misinformation: The Iraq War. Psychological Science, 16(2), 190-195. https://doi.org/10.1111/j.0956-7976.2005.00802.x

Moosavi, A. (2015). How to Write Death: Resignifying Martyrdom in Two Novels of the Iran-Iraq War. Alif: Journal of Comparative Poetics. 35(2), 9-31. http://www.jstor.org/stable/24772809

Masmoudi, I. (2010). Portraits of Iraqi Women: Between Testimony and Fiction. International Journal of Contemporary Iraqi Studies, 4(2), 59-77. https://doi.org/10.1386/ijcis.4.1-2.59_1

Masmoudi, I. (2015). War and Occupation in Iraqi Fiction. Edinburgh University Press: Edinburgh.

Mousa, L. (2018). War and Power Discourse in Iraqi Fiction. Al-alim Algedid. Retrieved from https://al-aalem.com/article

O'Gorman, D. (2015). Connective Dissonance: Refiguring Difference in Fiction of the Iraq War. In: Fictions of the War on Terror. Palgrave Macmillan. https://doi.org/10.1057/9781137506184_4

Root, M. P. (1996). Women of color and traumatic stress in "domestic captivity": Gender and race as disempowering statuses. In A. J. Marsella, M. J. Friedman, E. T. Gerrity, \& R. M. Scurfield (Eds.), Ethnocultural aspects of posttraumatic stress disorder: Issues, research, and clinical applications (pp. 363-387). American Psychological Association. https://doi.org/10.1037/10555-014

Saadawi, A. (2014). Frankenstein in Baghdad. Al-Kamel Verlag.

Said, E. (1993). Culture and Imperialism. Vintage.

\section{Copyrights}

Copyright for this article is retained by the author(s), with first publication rights granted to the journal.

This is an open-access article distributed under the terms and conditions of the Creative Commons Attribution license (http://creativecommons.org/licenses/by/4.0/). 